\title{
危険ドラッグ吸入曝露試験の開発
}

\author{
猪又明子, ${ }^{*, a}$ 小縣昭夫, ${ }^{a}$ 多田幸恵, ${ }^{a}$ 長澤明道, ${ }^{a}$ 晹澤勝廣, ${ }^{a}$ \\ 安藤 弘, ${ }^{a}$ 久保喜一, ${ }^{a}$ 高橋 博, ${ }^{a}$ 海鉾藤文, ${ }^{a}$ 田中和良, ${ }^{a}$ \\ 中嶋順一, ${ }^{a}$ 鈴木淳子, ${ }^{a}$ 植村望美, ${ }^{a}$ 守安貴子, ${ }^{a}$ 渡辺大介, $b$ \\ 石原 恵, $b$ 宇佐美 孝, $b$ 亀井 学, ${ }^{b}$ 河野安昭 $b$
}

\section{Inhalation Exposure Method for Illegal Drugs}

\author{
Akiko Inomata, ${ }^{*}, a$ Akio Ogata, ${ }^{a}$ Yukie Tada,${ }^{a}$ Akemichi Nagasawa, ${ }^{a}$ Katsuhiro Yuzawa, ${ }^{a}$ \\ Hiroshi Ando, ${ }^{a}$ Yoshikazu Kubo, ${ }^{a}$ Hiroshi Takahashi, ${ }^{a}$ Fujifumi Kaihoko, ${ }^{a}$ Kazuyoshi Tanaka, ${ }^{a}$ \\ Jun'ichi Nakajima, ${ }^{a}$ Atsuko Suzuki, ${ }^{a}$ Nozomi Uemura, ${ }^{a}$ Takako Moriyasu, ${ }^{a}$ Daisuke Watanabe, ${ }^{b}$ \\ Kei Ishihara, ${ }^{b}$ Takashi Usami, ${ }^{b}$ Satoru Kamei, ${ }^{b}$ and Yasuaki Kohno ${ }^{b}$ \\ ${ }^{a}$ Tokyo Metropolitan Institute of Public Health; 3-24-1 Hyakunin-cho, Shinjuku-ku, Tokyo 169-0073, Japan: and \\ ${ }^{b}$ Health and Safety Division, Bureau of Social Welfare and Public Health, Tokyo Metropolitan \\ Government; 2-8-1 Nishi-Shinjuku, Shinjuku-ku, Tokyo 163-8001, Japan.
}

(Received January 25, 2017; Accepted March 31, 2017)

\begin{abstract}
We developed a new inhalation exposure method to evaluate effects of synthetic cannabimimetics that are being distributed as new, unregulated drugs in the Tokyo area. We selected the commercial product "SOUTOU" containing ABCHMINACA and 5F-AMB as the test drug and dried marshmallow (Althaea officinalis) leaves as the negative control. A half cigarette packed with dried marshmallow leaves or SOUTOU was ignited, then mainstream smoke from each was delivered to five mice in an exposure box. After the cigarettes were fully consumed, neurobehavioral observations and a catalepsy test were performed at 15,30 and $60 \mathrm{~min}$ after exposure. The effluent air from the exposure box was poured into impingers containing acetonitrile (first impinger) and dimethyl sulfoxide (second impinger). The resulting solutions were analyzed to assess decomposition of the synthetic cannabimimetics. Mice exposed to SOUTOU smoke showed many excitement behaviors and some suppressive behaviors at 15,30 and $60 \mathrm{~min}$. These clearly included cannabimimetic specific pharmacological actions. Negative control mice also showed some suppressive behaviors at 15 min but these were attenuated at later times, nearly disappearing at $60 \mathrm{~min}$. In addition, the behavioral effects observed in controls were less pronounced than those in SOUTOU exposed mice. The inhalation exposure method developed in our study would be effective for determining cannabinoid specific pharmacological effects of illegal drugs, as well as for assessing the presence of active compound (s) by comparing the test substance with a negative control.
\end{abstract}

Key words_ inhalation exposure; neuro-behavioral observation; synthetic cannabimimetics; mouse

\section{は じめに}

東京都は，平成 17 年 4 月に「東京都薬物の濫用 防止に関する条例」を施行し，これまでに多くの危 険ドラッグに使用される成分を知事指定薬物として 規制してきた．知事指定薬物の指定に際しては，科 学的根拠に基づくデータが必要となつており，科学 的根拠に基づくデータの 1 つを得るために，実験動

${ }^{a}$ 東京都健康安全研究センター, ${ }^{b}$ 東京都福祉保健局健 康安全部

*e-mail: Akiko_Inomata@member.metro.tokyo.jp
物を用いた行動及び神経症状観察方法 ${ }^{1-4)}$ を開発し た.

この試験方法の概要は，被験物質を蒸留水に溶解 し，実験動物に経口投与した後， 30 分・1 時間・2 時間後に動物の行動及び神経症状を観察し，溶媒 （蒸留水）を投与した対照群の行動及び神経症状と 比較するものである.

平成 21 年以降，合成カンナビノイド化合物を含 有するハーブ系の危険ドラッグが流行してきてい る. ハーブ系の危険ドラッグは, Althaea officinalis （以下マーシュマロウと表記）等の支持植物に合成 カンナビノイド化合物の粉末をまぶした状態で販売 
されていることが多く，その使用方法は，危険ド ラッグをタバコのように燃焼させて，主流煙を吸引 するものである.

合成カンナビノイドは水にほとんど溶解せず，ま た有機溶媒に溶解させて実験動物に投与すると, 試 験結果に有機溶媒による影響が出ることから，既法 を用いて経口投与や腹腔内投与により生体影響を評 価することは極めて困難であった。合成カンナビノ イドの生体影響評価には, 使用実態に近い吸入曝露 試験方法を用いることが適切であることから，危険 ドラッグの吸入曝露試験について文献調査を行った が，発見に至らなかった。このため，ハーブ系の危 険ドラッグの生体影響を評価するスクリーニング法 として，危険ドラッグを燃焼させて生じた主流煙を 実験動物に曝露し，その動物の行動及び神経症状観 察を行うための吸入曝露装置を開発し，その実用性 を評価した。また，燃焼により合成カンナビノイド の成分が分解する可能性があることから，吸入曝露 装置の排気を回収し，成分を分析することにより， 燃焼によるこれら合成カンナビノイドの化学的な変 化の有無について検証を行つた.

試験薬物として，平成 26 年 6 月に東京都内で人 身事故を起こした危険ドラッグ製品に含まれていた 合成カンナビノイド化合物である AB-CHMINACA (1), 5-fluoro-AMB (5F-AMB, 2)(化学構造は Fig. 1) を用いた。

さらに，1-2 のヒトカンナビノイド受容体 $\left(\mathrm{CB}_{1}\right.$ 及び $\mathrm{CB}_{2}$ ）に対するアゴニスト活性を明らかにする ため, ヒトリコビナント受容体を用いて， ${ }^{35} \mathrm{~S}$ で標 識した Guanosine $5^{\prime}$-( $\gamma$-thio) Triphosphate ${ }^{\left({ }^{35} \mathrm{~S}-\right.}$ GTP $\gamma \mathrm{S}$ ）結合を指標とした受容体機能評価試験を 実施した。1-2のアゴニスト活性の試験結果と, 吸 入曝露試験の結果とを比較検討し, 開発した試験法 の評価を試みた。

\section{材料及び方法}

1. 吸入曝露装置 吸入曝露装置は, 人工呼吸 器（SN-480-5，シナノ製作所，東京），燃焼部，曝

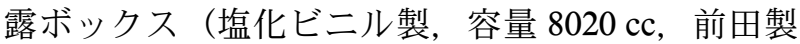
作所, 東京), ガス回収瓶 (SPCミゼットインピン ジャー, SIBATA, 草加：Impinger）により構成し た（Fig. 2)。燃焼から排気までの空気の流れは以 下の通りである．燃燒部で燃焼させた支持植物マー

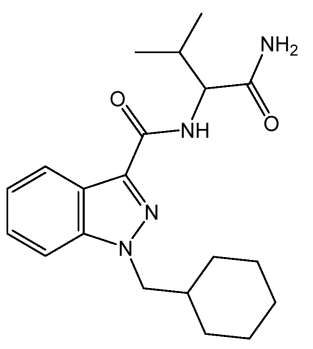

AB-CHMINACA (1)

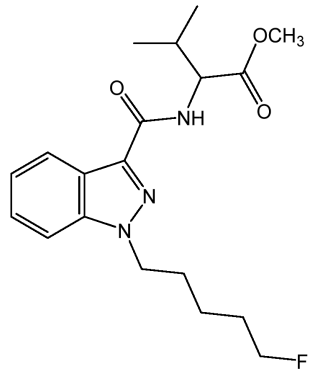

$5 \mathrm{~F}-\mathrm{AMB}(\mathbf{2})$
Fig. 1. Chemical Structures of Synthetic Cannabimimetics 12 Dealt in This Study

シュマロウの煙を人工呼吸器で設定した空気量で吸 引し，曝露ボックスの給気口に導入する．曝露ボッ クスの給気部にファン（E122535H，アース製薬， 東京）を設置し，流入した煙をボックス内に拡散さ せる．曝露ボックス内の煙を人工呼吸器で設定した 空気量で排気口から排気する，排気された煙をアセ トニトリル（1 本目：HPLC 用，和光純薬，大阪） と, ジメチルスルホキシド (2 本目 : 特級, 和光純 薬，大阪）の入った 2 連のガス回収装置でトラップ し, 煙中の危険ドラッグ成分を回収した後, 安全 キャビネット（HEPA フィルター付）から排気す る. 人工呼吸器以外の装置をすべて安全キャビネッ 卜内に設置し，燃焼に伴う煙等を安全キャビネット からスクラバー（活性炭付）を経て外気に放出する ことにより，試験実施者及び環境への薬物の曝露及 び放出を防御した。

2. 試験対象薬物及び陰性対照 試験対象薬物 として，平成 26 年 6 月に都内で起きた死亡事故に おいて，事故者が使用していた薬物「総統」の任意 提供品を用い，陰性対照として「総統」の支持植物 として繁用されているマーシュマロウの葉部（以下 マーシュマロウリーフと表記）を用いた.

「総統」の試験量は，実際の使用量が定かでない ため, タバコ $1 / 2$ 本に充てんされる量 $(0.25 \mathrm{~g})$ を 高用量（成分 $1: 6.1 \mathrm{mg}$, 成分 $2: 38.7 \mathrm{mg}$ ）（成分 1 及び 2 は，平成 26 年 7 月 15 日付けで指定薬物に 指定）とし，その $1 / 10$ 量 $(0.025 \mathrm{~g})$ を低用量（成 分 $1: 0.6 \mathrm{mg}$ ，成分 $2: 3.9 \mathrm{mg}$ ）として予備試験を 実施した。その結果，低用量ではほとんど影響がみ られず，高用量では曝露中に激しく暴れまわつた 後，瀕死状態となつたことから，この 2 用量の間に 適切な濃度があると考え，成分の 1 及び 2 をそれぞ 


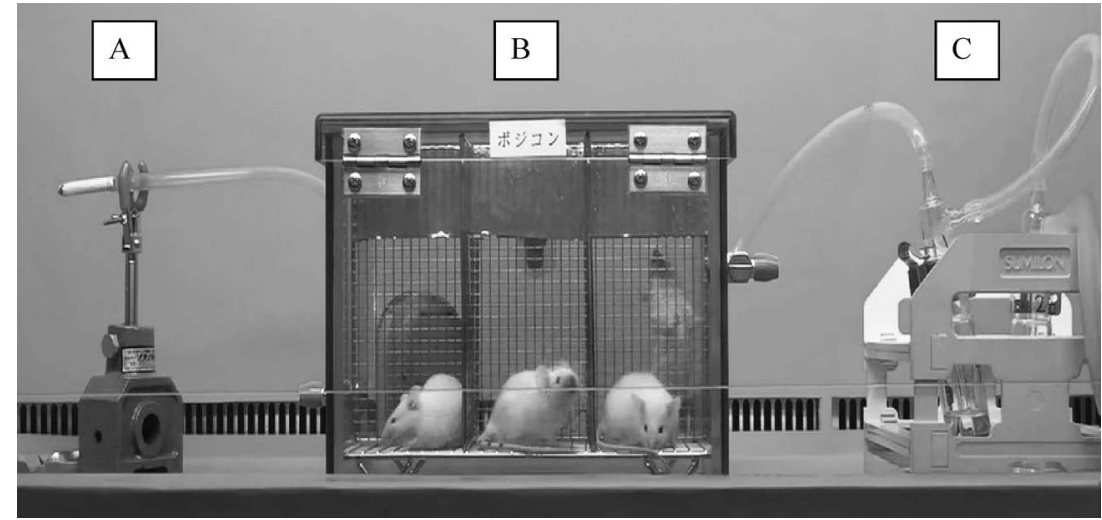

Fig. 2. Inhalation Exposure System A: Ignition part, B: Exposure box, C: Impingers.

れ $2 \mathrm{mg}$ 及び $13 \mathrm{mg}$ 含有する $0.08 \mathrm{~g}$ を試験量とした.

燃焼量は, さや紙 $1 / 2$ 本を充填する $0.25 \mathrm{~g}$ とし た。「総統」の試験には「総統」 $0.08 \mathrm{~g}$ 及びマー シュマロウリーフ $0.17 \mathrm{~g}$ をさや紙に充てんして使 用し，陰性対照にはマーシュマロウリーフ $0.25 \mathrm{~g}$ を使用した。

3. 実験動物 Crlj:CD1（ICR）雄マウス（日 本チャールス・リバー, 横浜）を 5 週齢時に購入 し，馴化して 6 週齢に達した発育良好なもの（体重 30-35 g）を試験に使用した.

4. 飼育条件動物は, 温度 $23-25^{\circ} \mathrm{C}$, 湿度 45-55\%，照明午前 6 時一午後 6 時，換気毎時 10 回 （HEPA フィルター経由）の飼育室において, 固形 飼料 CE-2（日本クレア，東京）及び限外ろ過処理 した水道水を自由に与え, プラスチックケージに 1 匹ずつ飼育した。

\section{5. 吸入曝露試験 マーシュマロウリーフ} （「総統」を添加したものも含む）を燃焼させるため に，タバコ両切り用さや紙にこれらを充てんし，吸 入曝露装置の燃焼部に設置した.

マウス 5 匹を，網で個別に仕切られた曝露ボック 又（容量 $8020 \mathrm{cc}$ ）に入れ，ふたを閉めた後，人工 呼吸器で毎分 $600 \mathrm{cc}$ の流速で空気を流入させなが ら，マーシュマロウリーフを燃焼させた。燃焼終了 後も人工呼吸器を運転し続け, 曝露ボックス内の空 気が外気とほぼ入れ替わる 15 分後に, マウスを曝 露ボックスから取り出し, 各試験を実施した.

6. 試験方法 燃焼終了後 15 分, 30 分, 60 分 の時点で，下記の試験を実施した。なお，体温測定 は，曝露前にも行った。
6-1. 行動及び中枢 · 自律神経症状観察 Irwin $^{5)}$ の多元観察法を改良した行動及び神経症 状観察得点表を作成し， 5 匹のスコアの平均值を求 めた．正常な動物の行動を 0 とし，抑制作用の認め られるものはマイナスに, 興奮作用の認められるも のはプラスに, 強さの程度に応じて, それぞれ 3 段 階の得点（抑制作用; $-1,-2,-3$, 興奮作用; $+1, \quad+2, \quad+3)$ を与えた。観察項目毎に得点を合 計して平均值を求め, 各項目における生体作用の強 度を判定した。

Tables 1-3に，行動及び中枢・自律神経症状観察 の得点表を示す.

行動及び神経症状観察で得られた各観察項目の数 值について， 5 匹の平均得点の絶対值が $0 \leqq$ 数值 0.4 の範囲であった場合は，生体影響はないものと した。観察項目の 1 つでも数值が $0.6 \leqq$ 数值 $\leqq 0.8$ の範囲であった場合は，生体影響が疑われるとし た。数值が $1.0 \leqq$ 数值 3.0 の範囲であった場合 は，生体影響があると判定した。

6-2. 体温測定 マウス用体温記録計 (AD-1687, エー・アンド・デイ，東京）を用いて， マウスの直腸温度を測定した.

曝露前の体温の $\pm 0.5^{\circ} \mathrm{C}$ を正常範囲とし，正常範 囲の下限から $1^{\circ} \mathrm{C}$ 低下する毎に抑制作用の得点 $(-1,-2,-3)$ を，上限から $1^{\circ} \mathrm{C}$ 上昇する毎に興 奮作用の得点 $(+1,+2,+3)$ を与え， 5 匹のマ ウスの平均值から作用強度を判定した [自律神経症 状観察の平均評価值（Table 3）の「体温」]。

6-3. カタレプシー試験高さ $6.5 \mathrm{~cm}$ の針金 の横棒にマウスの前脚をかけ，後脚を台上に降ろし 
Table 1. Observation Items in General Behavior and the Score in Symptom

\begin{tabular}{|c|c|c|c|c|c|c|c|}
\hline \multirow{2}{*}{$\begin{array}{l}\text { Observation } \\
\text { items }\end{array}$} & \multicolumn{3}{|c|}{ Suppressive behavior } & \multirow{2}{*}{$\begin{array}{c}\text { Normal } \\
0\end{array}$} & \multicolumn{3}{|c|}{ Excitement behavior } \\
\hline & -3 & -2 & -1 & & +1 & +2 & +3 \\
\hline Aggressiveness & & & & No reaction & $\begin{array}{l}\text { Reaction } \\
\text { a little }\end{array}$ & $\begin{array}{l}\text { A lot of } \\
\text { reaction }\end{array}$ & Very strong \\
\hline Passivity & Not escape & $\begin{array}{l}\text { Hardly run } \\
\text { away }\end{array}$ & $\begin{array}{l}\text { Run away } \\
\text { a little }\end{array}$ & $\begin{array}{l}\text { Escape from } \\
\text { holding }\end{array}$ & & & \\
\hline Stereotypy & & & & $\begin{array}{l}\text { Usual } \\
\text { frequency }\end{array}$ & A little & $\begin{array}{l}\text { A lot of } \\
\text { frequency }\end{array}$ & Numerous \\
\hline Grooming & Not at all & Small frequency & A little few & $\begin{array}{c}\text { Moves } \\
\text { moderately }\end{array}$ & A little lot & $\begin{array}{l}\text { A lot of } \\
\text { frequency }\end{array}$ & Numerous \\
\hline Vocalization & & & & Not vocalize & $\begin{array}{c}\text { A little } \\
\text { vocalize }\end{array}$ & $\begin{array}{c}\text { A lot of } \\
\text { vocalization }\end{array}$ & $\begin{array}{c}\text { Vocalize } \\
\text { numerously }\end{array}$ \\
\hline Sound response & Not respond & Weak & A little weak & Respond & A little strong & Strong & Excessive \\
\hline Touch response & Not respond & Weak & A little weak & Respond & A little strong & Strong & Excessive \\
\hline Pain response & Not respond & Weak & A little weak & Respond & A little strong & Strong & Excessive \\
\hline Verticalness & Not at all & Small frequency & A little few & $\begin{array}{c}\text { Moves } \\
\text { moderately }\end{array}$ & A little lot & $\begin{array}{l}\text { A lot of } \\
\text { frequency }\end{array}$ & Numerous \\
\hline
\end{tabular}

Table 2. Observation Items in Neurogical Behavior and the Score in Symptom

\begin{tabular}{|c|c|c|c|c|c|c|c|}
\hline \multirow{2}{*}{$\begin{array}{l}\text { Observation } \\
\text { items }\end{array}$} & \multicolumn{3}{|c|}{ Suppressive behavior } & \multirow{2}{*}{$\begin{array}{c}\text { Normal } \\
0\end{array}$} & \multicolumn{3}{|c|}{ Excitement behavior } \\
\hline & -3 & -2 & -1 & & +1 & +2 & +3 \\
\hline $\begin{array}{l}\text { Spontaneous } \\
\text { activity }\end{array}$ & No activity & Hardly moves & Badly moves & $\begin{array}{c}\text { Moves } \\
\text { moderately }\end{array}$ & $\begin{array}{c}\text { Good } \\
\text { movement }\end{array}$ & $\begin{array}{c}\text { A lot of } \\
\text { momentums }\end{array}$ & Runs \\
\hline Abnormal gait & $\begin{array}{l}\text { Difficulty in } \\
\text { walking }\end{array}$ & $\begin{array}{c}\text { Walking } \\
\text { staggeringly }\end{array}$ & Drag walking & Normal walking & Walking a little & Walking busily & $\begin{array}{l}\text { Jumping up } \\
\text { and down }\end{array}$ \\
\hline $\begin{array}{l}\text { Abnormal } \\
\text { position }\end{array}$ & $\begin{array}{l}\text { Difficulty } \\
\text { maintenance }\end{array}$ & $\begin{array}{l}\text { Instability } \\
\text { position }\end{array}$ & Inclines a little & Normal position & & & \\
\hline Muscle tone & Insensibility & Weak & A little weak & $\begin{array}{l}\text { Moderate } \\
\text { resistance }\end{array}$ & A little strong & Strong & Rigor \\
\hline $\begin{array}{l}\text { Straus tail } \\
\text { reaction }\end{array}$ & & & & No reaction & A little & A lot of & Numerous \\
\hline Righting reflex & Not get back & $\begin{array}{l}\text { Take } 5 \text { seconds } \\
\text { to get back }\end{array}$ & A little slow & $\begin{array}{c}\text { Get back } \\
\text { immediately }\end{array}$ & & & \\
\hline Pinna reflex & Not brushes & Weak & A little weak & $\begin{array}{l}\text { Dislike and } \\
\text { brushes off }\end{array}$ & A little strong & Strong & $\begin{array}{l}\text { Excessive } \\
\text { reaction }\end{array}$ \\
\hline Corneal reflex & No response & Weak & A little weak & Shut eyelid & A little strong & Strong & $\begin{array}{l}\text { Excessive } \\
\text { reaction }\end{array}$ \\
\hline Tendon reflex & No response & Weak & A little weak & Kick foot & A little strong & Strong & $\begin{array}{l}\text { Excessive } \\
\text { reaction }\end{array}$ \\
\hline Tremor & & & & Not tremble & Tremble a little & Tremble & $\begin{array}{l}\text { Tremble } \\
\text { violently }\end{array}$ \\
\hline Convulsion & & & & Not convulse & Convulse a little & Convulse & $\begin{array}{l}\text { Convulse } \\
\text { violently }\end{array}$ \\
\hline Grip strength & Not grasp & Weak & A little weak & Normal & A little strong & Strong & Grasp strongly \\
\hline Detached finger & Open greatly & Open finger & Close a little & Close & & & \\
\hline
\end{tabular}

て 2 本足で立たせたまま，動かない秒数を計時した. 30 秒以上動かない場合をカタレプシー陽性とし, 最大 90 秒まで計時した. 30 秒未満の場合には試験 を 3 回まで繰り返し, 3 回とも 30 秒未満で動いた 場合はカタレプシー陰性とした。

7. 実験動物の取り扱い 6. に記述した試験
は，東京都健康安全研究センターの動物実験委員会 において審査され，承認されたものである。動物実 験の実施においては，動物の愛護及び管理に関する 法律（昭和 48 年法律第 105 号）, 実験動物の飼養及 び保管並びに苦痛の軽減に関する基準（平成 18 年 環境省告示第 88 号), 厚生労働省の所管する実施機 
Table 3. Observation Items in Autonomical Behavior and the Score in Symptom

\begin{tabular}{|c|c|c|c|c|c|c|c|}
\hline \multirow{2}{*}{$\begin{array}{l}\text { Observation } \\
\text { items }\end{array}$} & \multicolumn{3}{|c|}{ Suppressive behavior } & \multirow{2}{*}{$\begin{array}{c}\text { Normal } \\
0\end{array}$} & \multicolumn{3}{|c|}{ Excitement behavior } \\
\hline & -3 & -2 & -1 & & +1 & +2 & +3 \\
\hline Exophthalmos & & & & Not come out & $\begin{array}{l}\text { A little } \\
\text { come out }\end{array}$ & Come out & $\begin{array}{l}\text { Come out } \\
\text { strongly }\end{array}$ \\
\hline Pupil size & Very small & Small & A little small & Normal & A little big & Big & Very big \\
\hline $\begin{array}{l}\text { Palpebral } \\
\text { opening }\end{array}$ & While close & Close a half & Close a little & Normal opening & Open a little & Open a half & While open \\
\hline Shed tears & & & & Normal & A little lot & A lot & Numerous \\
\hline Urination & Very few & Few & A little few & Normal & A little lot & A lot & Numerous \\
\hline $\begin{array}{l}\text { State of } \\
\text { excrement }\end{array}$ & Diarrhea & Loose & Loose a little & Normal & Hard a little & Hard & Very hard \\
\hline $\begin{array}{l}\text { Frequency of } \\
\text { excrement }\end{array}$ & Very few & Few & A little few & Normal & A little lot & A lot & Numerous \\
\hline Salivation & & & & No salivation & A little lot & A lot & Numerous \\
\hline Respiratory rate & Very few & Few & A little few & Normal & A little lot & A lot & Numerous \\
\hline Heart rate & Very few & Few & A little few & Normal & A little lot & A lot & Numerous \\
\hline Piloerection & & & & No erection & Erect a little & Erect & Erect violently \\
\hline Temperature & Very low & Low & A little low & Normal & A little high & High & Very high \\
\hline Skin color & Very white & White & A little white & Normal & Redness a little & Redness & Very redness \\
\hline
\end{tabular}

関における動物実験等の実施に関する基本指針（平 成 18 年 6 月 1 日厚生労働省大臣官房厚生科学課長 通知），動物の殺処分方法に関する指針（平成 19 年 環境省告示第 105 号)，動物実験の適正な実施に向 けたガイドライン（平成 18 年 6 月 1 日日本学術会 議)，東京都動物の愛護及び管理に関する条例（昭 和 54 年条例第 81 号）に基づき，東京都健康安全研 究センター動物実験実施規程, 同実験動物施設管理 基準及び標準作業手順書に従って実施した.

\section{8. ガス回収装置中の成分分析 曝露装置に,} 溶媒を入れた 2 本のガス回収装置を接続し燃焼によ り生じる薬物を捕集した。 1 本目のガス回収装置に はアセトニトリル，2 本目にはジメチルスルホキシ ドを各々 $20 \mathrm{~mL}$ 入れ, 曝露装置を経た気体を通液 させた．曝露後のガス回収装置中のアセトニトリル は $60^{\circ} \mathrm{C}$ の水浴中で減圧濃縮し, ジメチルスルホキ シドは $60^{\circ} \mathrm{C}$ の恒温で真空式ボルテックス濃縮機 （バイオクロマト, 藤沢）により濃縮した。濃縮後 の残留物に $5 \mathrm{~mL}$ のアセトニトリルを正確に加え, 超音波を照射して残留物を溶解した。この一部を $0.2 \mu \mathrm{m}$ のフィルターでろ過し機器分析用試料溶液 とした.

機器分析はフォトダイオードアレイ検出器付液体 クロマトグラフィー（LC/PDA），電子イオン化質 量分析計付ガスクロマトグラフィー (GC/EI-MS)
により行った. LC/PDA 条件 : 機器, ACQUITY UPLC PDA system（日本ウォーターズ, 東京) ; カ ラム, ACQUITY UPLC HSS T3 $1.8 \mu \mathrm{m}$ (50 mm× $2.1 \mathrm{~mm}$ i.d., 日本ウォーターズ, 東京) ; カラム温 度, $40^{\circ} \mathrm{C}$; 溶離液 $\mathrm{A}, 0.1 \%$ ギ酸水; 溶離液 $\mathrm{B}, 0.1 \%$ ギ酸含有アセトニトリル ; グラジエント条件, 00.50 分, 溶離液 $\mathrm{A} / \mathrm{B}=99 / 1,0.50-6.85$ 分, 同 99/1 $\rightarrow 10 / 90,6.85-8.85$ 分, 同 10/90 $\rightarrow 1 / 99$; 流量, $0.6 \mathrm{~mL} /$ 分; 注入量, $1 \mu \mathrm{L}$; 測定波長, $200-400$ $\mathrm{nm}$; デー夕解析, Empower 2(日本ウォーターズ, 東京)。 GC/EI-MS の条件：機器, 7890A/5975C (アジレント・テクノロジー, 八王子). カラム及び カラム温度, HP-5MS $(30 \mathrm{~m} \times 0.25 \mathrm{~mm}$ i.d., 膜厚 $0.25 \mu \mathrm{m}$, アジレント・テクノロジー, 八王子), $50^{\circ} \mathrm{C}$ (1 分) $\rightarrow 10^{\circ} \mathrm{C} /$ 分 $\rightarrow 325^{\circ} \mathrm{C}$ (10 分) ; キャリアー ガス, $\mathrm{He}$; ガス流量, $1 \mathrm{~mL} /$ 分; 注入法, スプ リット (スプリット比 $10 ： 1$ ) 又はスプリットレス； 注入口温度, $250^{\circ} \mathrm{C}$; 注入量, $1 \mu \mathrm{L}$; イオン化法, $\mathrm{EI}$ 法 ; イオン化電圧, $70 \mathrm{eV}$; トランスファーライ ン温度, $250^{\circ} \mathrm{C}$; 四重極温度, $150^{\circ} \mathrm{C}$; イオン源温度, $250^{\circ} \mathrm{C}$; デー夕解析, ChemStation（アジレント・ テクノロジー，八王子)。なお使用した試薬は HPLC 用又は LC/MS 用を用いた.

9. カンナビノイド受容体に対するアゴニスト活

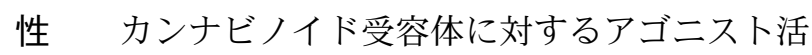


性は，積水メディカル株式会社に委託して実施し た. クローンレセプター (Cannabinoid $\mathrm{CB}_{1}$, Cannabinoid $\mathrm{CB}_{2}$ ) は市販のレセプター（HTS019M 及 び HTS020M2, Eurofins, Luxembourg）を標品とし て用い，陽性物質として CP55940（C-1112, SigmaAldrich, St. Louis）を，トレーサーには ${ }^{35} \mathrm{~S}-\mathrm{GTP} \gamma \mathrm{S}$ (NEG030H, PerkinElmer Life \& Analytical Sciences, Waltham）を用いた.

陽性物質及び被験物質 1-2 は，いずれもジメチル スルホキシドで溶解・希釈し， $1 \times 10^{-10}-1 \times 10^{-3}$ $\mathrm{mol} / \mathrm{L}$ の 10 倍連続希釈溶液を調製し，さらに各濃 度の溶液を超純水で 10 倍希釈し, 最終濃度の 10 倍 濃度溶液を調製した。陽性物質の $1 \times 10^{-5} \mathrm{~mol} / \mathrm{L}$ は，100\%反応溶液としても使用した。測定数は, 総結合算出に 2 連， $100 \%$ 反応量算出に 4 連，陽性 物質及び被験物質の反応量算出に 2 連とし，それぞ れ異なる日に 2 回測定した.

総結合算出用チューブに $10 \%$ ジメチルスルホキ シド， $100 \%$ 反応量算出チューブに $100 \%$ 反応溶 液，陽性物質及び被験物質の反応量算出チューブに 陽性物質溶液あるいは被験物質溶液を各 $50 \mu \mathrm{L}$ 添加 し, $20 \mathrm{mmol} / \mathrm{L}$ HEPES-NaOH（pH 7.4）を $100 \mu \mathrm{L}$, トレーサー溶液を $100 \mu \mathrm{L}$, GDP 溶液を $50 \mu \mathrm{L}$, レセプター溶液を $200 \mu \mathrm{L}$ 添加し， $30^{\circ} \mathrm{C} て ゙ 60$ 分 間インキュベート後，セルハーベスター（M-30R， BRANDEL, Gaithersburg）によりろ過（GF/C, Whatman, Maidstone, PBS 処理）し，水冷した PBS $3 \mathrm{~mL}$ で 3 回洗浄後，ろ紙を測定バイアル瓶に 移して液体シンチレーター (PICO-FLUOR PLUS, PerkinElmer Life \& Analytical Sciences, Waltham) $5 \mathrm{~mL}$ を添加し, 液体シンチレーションカウンター (2500 型及び 3100 型, PerkinElmer Life \& Analytical Sciences, Waltham) で 2 分間測定した.

反応率は，以下の式から算出した。

反応率 : $\left[\left(\mathrm{B}-\mathrm{B}_{0}\right) /\left(\mathrm{B}_{\max }-\mathrm{B}_{0}\right)\right] \times 100(\%)$

$\mathrm{B}$ : 陽性物質・被験物質存在下での反応放射能量 (個別値)

$\mathrm{B}_{0}$ ：陽性物質・被験物質非存在下での反応放射能 量（平均值）

$\mathrm{B}_{\max }$ ：最大反応溶液（アゴニスト溶液）存在下で の反応放射能量（平均值）

陽性物質及び被験物質の 2 測定の反応率が，反応 率平均值の $\pm 10 \%$ 以内の場合に測定值を採用した。
この条件を満たさない場合は，陽性物質及び被験物 質すべての再測定を実施し，基準を満たした場合の 再測定值を採用した。

陽性物質及び被験物質のレセプターに対する最大 反応の $50 \%$ を示す濃度（ $\mathrm{EC}_{50}$ 值）を算出し，アゴ ニスト活性を評価した． $\mathrm{EC}_{50}$ 值は，以下のロジス ティックモデルによる非線形回帰の結果から推定し た.

$$
\begin{aligned}
& \mathrm{Y}=0+1 /\left[1+10^{\{-\beta \times(\mathrm{X}-\mathrm{ED} 0.5)\}}\right] \\
& \mathrm{Y}\left(\text { 反応量比) }:\left(\mathrm{B}-\mathrm{B}^{0}\right) /\left(\mathrm{B}_{\max }-\mathrm{B}_{0}\right)\right.
\end{aligned}
$$

$\mathrm{ED} 0.5: \mathrm{EC}_{50}$ の常用対数

$\beta:$ 傾き (Hill 係数)

$\mathrm{X}$ : 陽性物質・被験物質濃度の常用対数

結果

1. 行動及び中枢 · 自律神経症状観察 Tables 4-6に，陰性対照のマーシュマロウリーフ又は「総 統」を燃焼した煙を曝露したマウスにおける行動及 び中枢・自律神経症状観察の平均評価値を示した. 着火から燃え尽きるまでの燃焼時間は，マーシュマ ロウリーフで 1 分 55 秒,「総統」で 1 分 5 秒であっ た.

1-1. 行動観察「総統」曝露群では，曝露中 に激しい飛び跳ね，口を大きく開く，静止状態と激 しい飛び跳ねを繰り返す，呼吸が荒く瞼を閉じて ぐったりと網壁にもたれ掛かる様子がみられた (Fig. 3).

陰性対照群では，曝露開始後に一部の動物が網壁 をよじ登つたが，飛び跳ねはみられなかった，さら に曝露を続けると動きが鈍くなり，瞼を閉じて静止 する状態がみられた。しかし，「総統」曝露群でみ られた脱力感や，体勢の傾きはほとんど認められな かった (Fig. 4).

曝露後 15 分の観察時には，陰性対照群，「総統」 曝露群ともに，洗顔運動が強く抑制されていた。こ の反応は，陰性対照群では時間の経過とともに抑制 作用が減弱し，1 時間の観察時にはほとんど消失し たが，「総統」曝露群では 1 時間の観察時まで強い 抑制が続いていた．立ち上がり動作の抑制は，陰性 対照群においても認められたが，その作用強度は 「総統」曝露群よりも弱く, 特に 1 時間の観察時で は「総統」曝露群において強い抑制が認められたが, 陰性対照群では作用が減弱していた。さらに，「総 
Table 4. Mean Value of the Score in General Behavior

\begin{tabular}{|c|c|c|c|c|c|c|c|c|c|c|}
\hline \multicolumn{11}{|c|}{ Observation items } \\
\hline Group & $\begin{array}{l}\text { Observation } \\
\text { time }(\mathrm{h})\end{array}$ & Aggressiveness & Passivity & Stereotypy & Grooming & Vocalization & $\begin{array}{c}\text { Sound } \\
\text { response }\end{array}$ & $\begin{array}{l}\text { Touch } \\
\text { response }\end{array}$ & $\begin{array}{l}\text { Pain } \\
\text { response }\end{array}$ & Verticalness \\
\hline \multirow{3}{*}{$\begin{array}{l}\text { Marsh- } \\
\text { mallow }^{\text {a }}\end{array}$} & 0.25 & 0 & 0 & 0.2 & -2.8 & 0 & 0 & 0 & -0.4 & -0.6 \\
\hline & 0.5 & 0 & -0.6 & 0 & -1.4 & 0 & 0.2 & -0.2 & -0.2 & -1.6 \\
\hline & 1 & 0 & -0.6 & 0 & -0.4 & 0 & 0 & -0.4 & -0.2 & -0.8 \\
\hline \multirow{3}{*}{ SOUTOU $^{\mathrm{b}}$} & 0.25 & 1.2 & -1.8 & 1.0 & -3.0 & 0 & -1.8 & -2.8 & -2.4 & -1.2 \\
\hline & 0.5 & 0.8 & -1.0 & 0 & -3.0 & 0 & -1.6 & -1.4 & -1.4 & -2.6 \\
\hline & 1 & 0.6 & -1.0 & 0.6 & -3.0 & 0 & -1.6 & -1.0 & -0.6 & -3.0 \\
\hline \multicolumn{11}{|c|}{$\begin{array}{cl}\text { Strength level of the biological effect } & 0 \leqq \text { mean value } \leqq 0.4 \text { : Nothing } \\
& 0.6 \leqq \text { mean value } \leqq 0.8 \text { : Uncertain } \\
& 1.0 \leqq \text { mean value } \leqq 3.0 \text { : Certain } \\
& \\
{ }^{a} \text { Marshmallow is negative control. }{ }^{\mathrm{b}} \text { SOUTOU contains AB-CHMINAC }\end{array}$} \\
\hline \multicolumn{11}{|c|}{ Observation items } \\
\hline Group & $\begin{array}{l}\text { Observati } \\
\text { time }(\mathrm{h})\end{array}$ & $\begin{array}{r}\text { Spontane } \\
\text { activity }\end{array}$ & $\begin{array}{l}\text { cous } \\
y\end{array}$ & $\begin{array}{l}\text { bnormal } \\
\text { gait }\end{array}$ & $\begin{array}{l}\text { Abnormal } \\
\text { position }\end{array}$ & $\begin{array}{c}\text { Muscle } \\
\text { tone }\end{array}$ & $\begin{array}{l}\text { traus tail } \\
\text { reaction }\end{array}$ & $\begin{array}{l}\text { Righting } \\
\text { reflex }\end{array}$ & $\begin{array}{l}\text { Pinna } \\
\text { reflex }\end{array}$ & $\begin{array}{l}\text { Corneal } \\
\text { reflex }\end{array}$ \\
\hline \multirow{3}{*}{$\begin{array}{l}\text { Marsh- } \\
\text { mallow }^{\mathrm{a}}\end{array}$} & 0.25 & -0.8 & & 0 & 0 & 0 & 0 & 0 & 0 & 0 \\
\hline & 0.5 & -0.2 & & 0 & 0 & 0 & 0 & 0 & -0.2 & 0 \\
\hline & 1 & -0.2 & & 0 & 0 & 0 & 0 & 0 & -0.4 & 0 \\
\hline \multirow{3}{*}{ SOUTOU $^{\mathrm{b}}$} & 0.25 & -2.0 & & -3.0 & -3.0 & -2.0 & 0 & -2.6 & -2.2 & -2.0 \\
\hline & 0.5 & -1.8 & & -2.2 & -1.6 & -1.6 & 0.8 & -2.2 & -1.0 & -1.2 \\
\hline & 1 & -1.4 & & -1.8 & -1.4 & -1.4 & 0.8 & -1.0 & -0.2 & -0.8 \\
\hline
\end{tabular}

a Marshmallow is negative control. ${ }^{\mathrm{b}}$ SOUTOU contains AB-CHMINACA $2 \mathrm{mg}$ and 5F-AMB $13 \mathrm{mg}$.

Table 5-2. Mean Value of the Score in Neurogical Behavior

\begin{tabular}{ccccccc}
\hline \hline \multirow{2}{*}{ Group } & $\begin{array}{c}\text { Observation } \\
\text { time }(\mathrm{h})\end{array}$ & Tendon reflex & Tremor & Convulsion & Grip strength & Detached finger \\
\hline \multirow{3}{*}{ Marshmallow $^{\mathrm{a}}$} & 0.25 & 0 & 0 & 0 & 0 & 0 \\
& 0.5 & -0.6 & 0 & 0 & 0.4 & 0 \\
\hline \multirow{3}{*}{ SOUTOU $^{\mathrm{b}}$} & 1 & 0.2 & 0 & 0 & 0 & 0 \\
& 0.25 & -2.0 & 0 & 0 & -2.6 & -0.6 \\
& 0.5 & -1.0 & 0 & 0 & -1.6 & -1.0 \\
\hline
\end{tabular}

Strength level of the biological effect $0 \leqq$ mean value $\leqq 0.4$ : Nothing

$0.6 \leqq$ mean value $\leqq 0.8$ : Uncertain

$1.0 \leqq$ mean value $\leqq 3.0$ : Certain

a Marshmallow is negative control. ${ }^{b}$ SOUTOU contains AB-CHMINACA $2 \mathrm{mg}$ and 5F-AMB $13 \mathrm{mg}$.

統」曝露群においては, 消極性, 外界反応, 触反応 及び痛反応の抑制と, 攻撃性及び反復動作の充進が 認められた (Table 4).

1-2. 中枢神経症状観察曝露後 15 分の観察 時には，陰性対照群，「総統」曝露群ともに自発運
動が抑制されたが，その作用強度は陰性対照群では 弱かった。この反応の抑制は，陰性対照群では 30 分の観察時以降はほとんど消失したが，「総統」曝 露群では 1 時間の観察時まで継続して認められた。 さらに,「総統」曝露群では, 曝露後 15 分の観察時 
Table 6. Mean Value of the Score in Autonomical Behavior

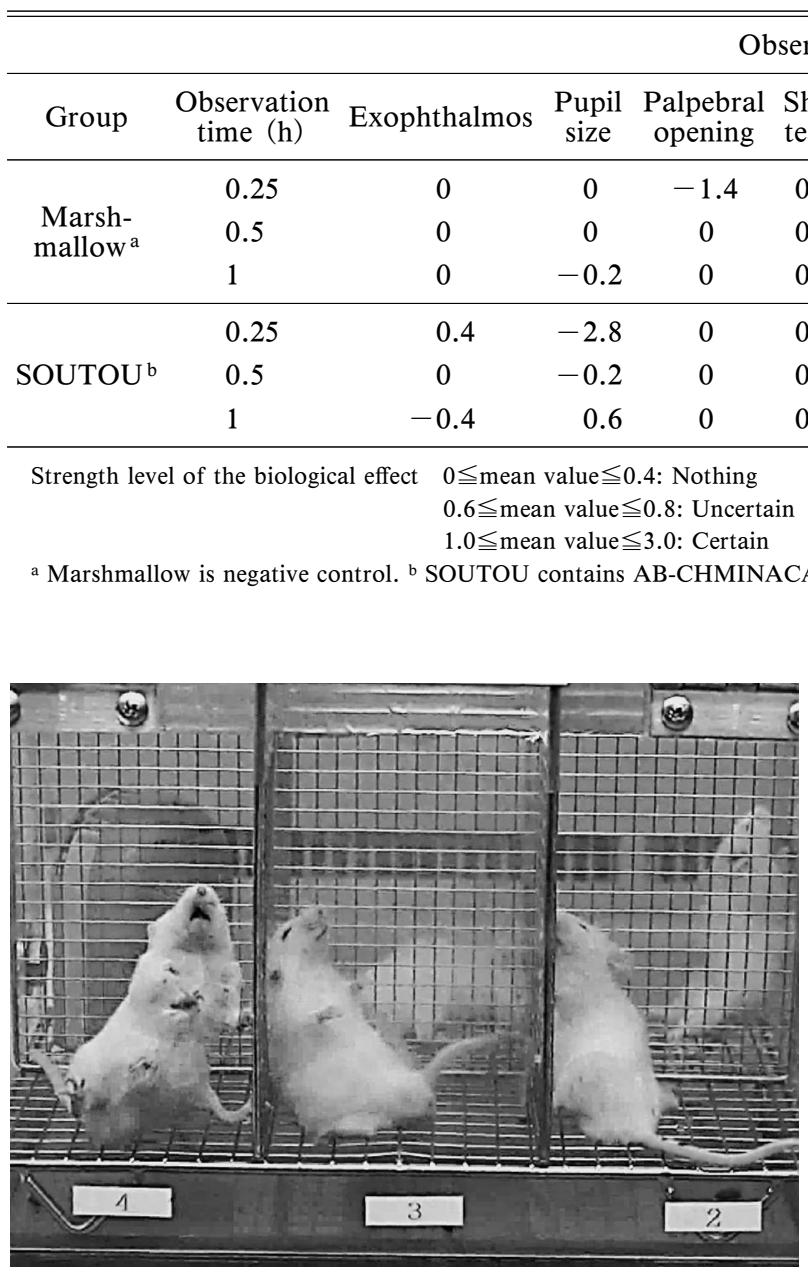

Fig. 3. SOUTOU Smoke Exposed Mice

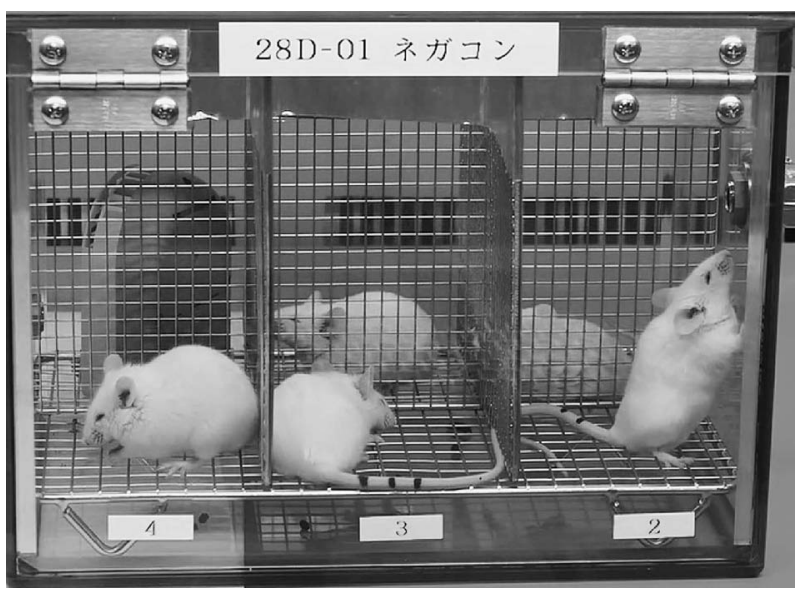

Fig. 4. Marshmallow Smoke Exposed Mice

から異常歩行, 異常姿勢, 筋緊張度, 正向反射, 耳 介反射，角膜反射，払いのけ，懸垂力の抑制が認め られ，これらの反応は時間の経過とともに減弱した
Table 7. Catalepsy Test

\begin{tabular}{lccc}
\hline \hline & $\begin{array}{c}\text { Observation } \\
\text { time (h) }\end{array}$ & $\begin{array}{c}\text { Marsh- } \\
\text { mallow } \\
\text { (Negative } \\
\text { control) }\end{array}$ & $\begin{array}{c}\text { SOUTOU } \\
\text { (AB-CHMINACA 2 mg, } \\
\text { 5F-AMB 13 mg) }\end{array}$ \\
\hline $\begin{array}{l}\text { Number of } \\
\text { positive } \\
\text { animals }\end{array}$ & 0.25 & 0 & 2 \\
& 0.5 & 0 & 2 \\
\hline
\end{tabular}

$n=5$.

が， 1 時間の観察時まで継続して認められた。 また， 30 分の観察時以降に挙尾反応及び指間離開が観察 された (Tables 5-1 and 5-2).

1-3. 自律神経症状観察曝露後 15 分の観察 時には, 陰性対照群,「総統」曝露群ともに, 眼裂 及び体温に抑制の影響がみられた。陰性対照群にお ける体温の低下（平均 $2.3^{\circ} \mathrm{C}$ ) は, 「総統」曝露群 での体温低下 (平均 $3.5^{\circ} \mathrm{C}$ ) よりも作用強度が弱く, 眼裂の抑制も陰性対照群において作用強度が弱かつ た. 陰性対照群では, 曝露後 30 分の観察時以降, 体温の低下 $\left(30\right.$ 分後平均 $1.8^{\circ} \mathrm{C}, 1$ 時間後平均 0.7 $\left.{ }^{\circ} \mathrm{C}\right)$ 以外の反応はほとんぞ消失した。「総統」曝露 群では，さらに呼吸数及び心拍数の抑制がみられ， 呼吸数及び心拍数の抑制と体温低下が曝露後 1 時間 の観察時まで同程度の作用強度で続いた．体温は曝 露後 15 分で平均 $3.5^{\circ} \mathrm{C}, 30$ 分で $5.2^{\circ} \mathrm{C}, 1$ 時間で $5.9^{\circ} \mathrm{C}$ 低下した。眼裂は 30 分後に抑制作用がほと んど消失し， 1 時間後にはやや充進が認められた (Table 6).

2. カタレプシー試験 カタレプシー試験結果 を Table 7 に示した。陰性対照群では, 曝露後 15 

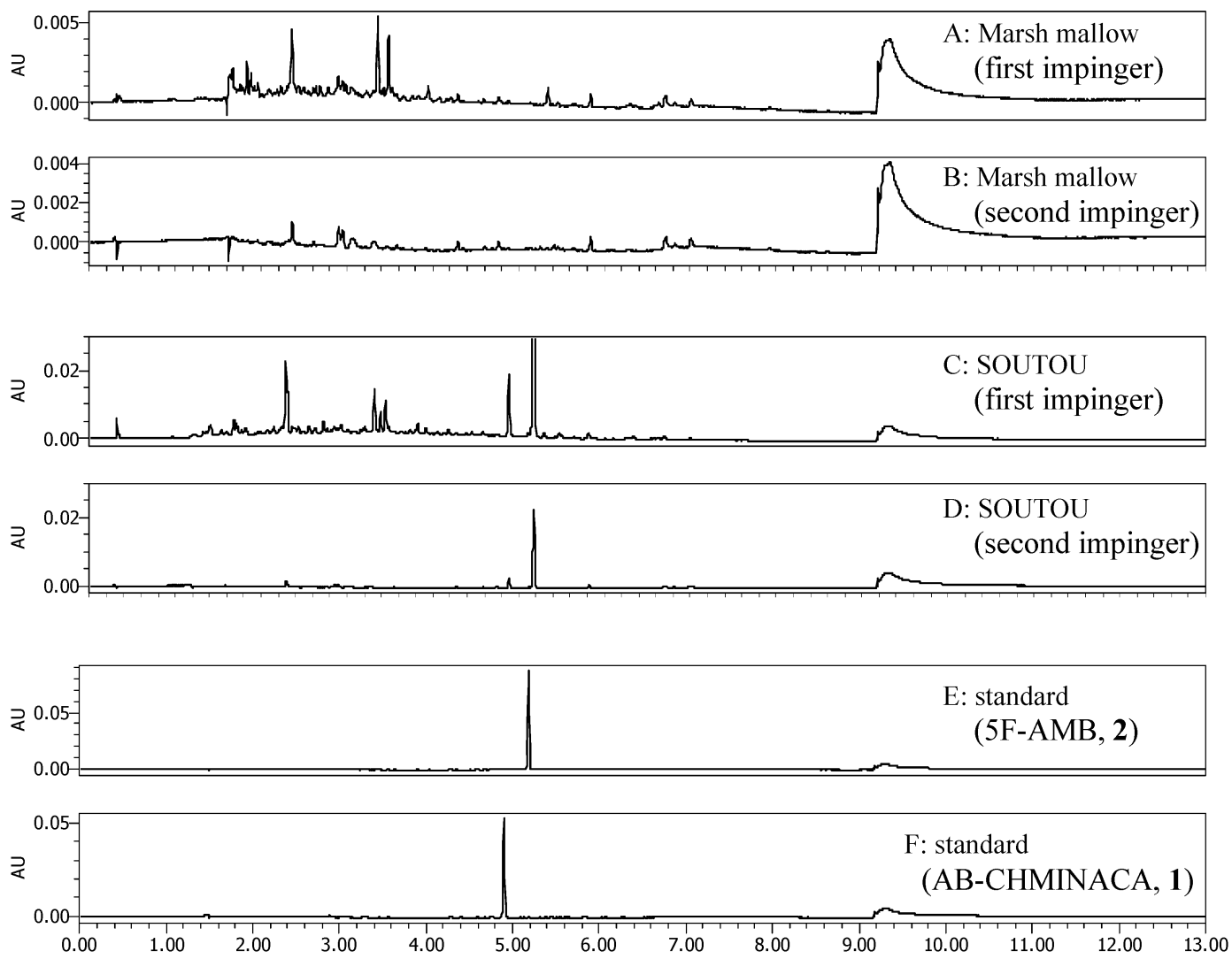

Time (min.)

Fig. 5. Liquid Chromatograms with a UV Detection at $275 \mathrm{~nm}$ of Marshmallow (A, B), SOUTOU (C, D), 5F-AMB (E) and ABCHMINACA (F) with Combustion Experiment

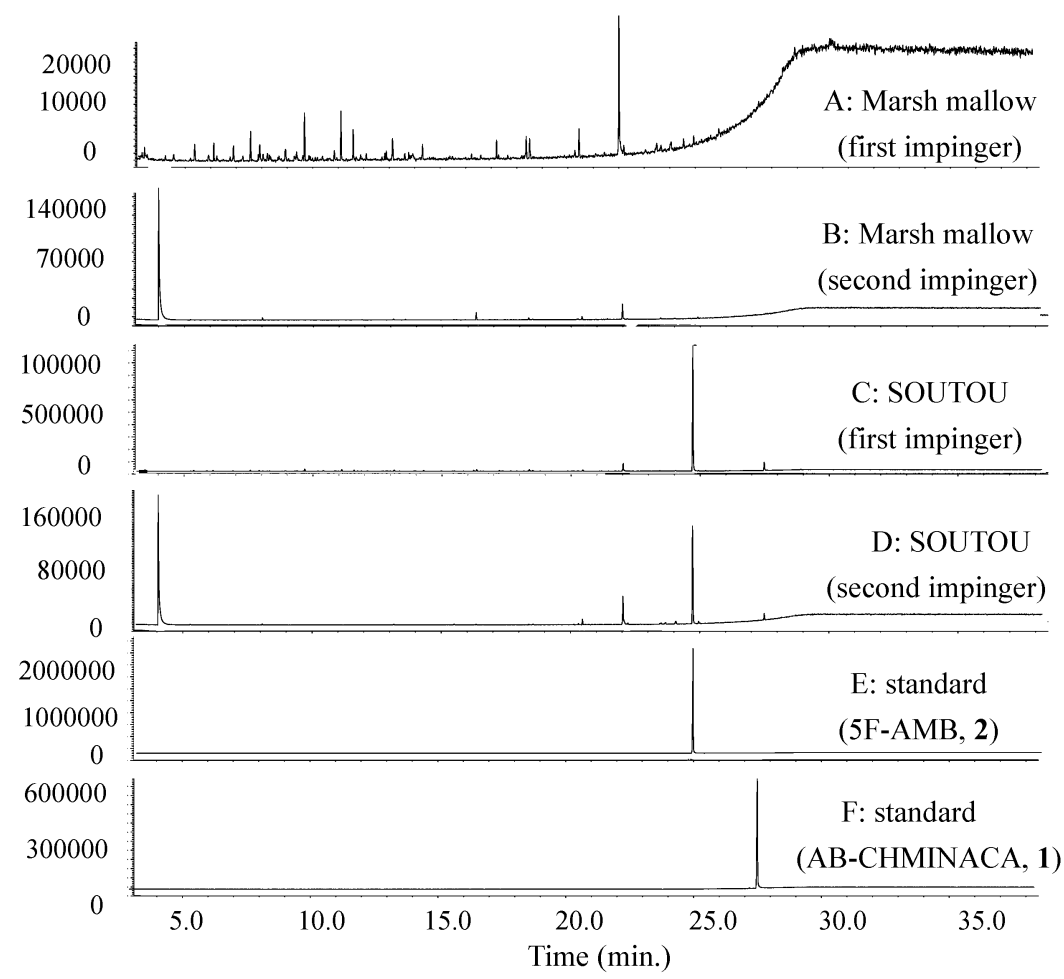

Fig. 6. Total Ion Chromatograms Recorded by the GC-MS for the Marshmallow (A, B), SOUTOU (C, D), 5F-AMB (E) and ABCHMINACA (F) with Combustion Experiment 
Table 8. Response Rate (\%) and Mean $\mathrm{EC}_{50}$ (mol/L) of ${ }^{35} \mathrm{~S}-\mathrm{GTP} \gamma \mathrm{S}$ Binding of Test Substances on Cannabinoid $\mathrm{CB}_{1}$ (Human) and Cannnabinoid $\mathrm{CB}_{2}$ (Human) Receptors

\begin{tabular}{lcccc}
\hline \hline \multicolumn{1}{c}{ Substance } & $\begin{array}{c}\text { Cannabinoid } \mathrm{CB}_{1}(\text { Human }) \\
\text { Response rate } \\
(\%)\end{array}$ & $\begin{array}{c}\text { Cannabinoid } \mathrm{CB}_{2} \text { (Human) } \\
(\mathrm{mol} / \mathrm{L})\end{array}$ & $\begin{array}{c}\text { (Hon })_{50} \\
\text { Response rate }\end{array}$ & $\begin{array}{c}\text { Mean } \mathrm{EC}_{50} \\
(\mathrm{~mol} / \mathrm{L})\end{array}$ \\
\hline AB-CHMINACA & $100.00,100.00$ & $2.26 \times 10^{-10}$ & $100.00,100.00$ & $1.52 \times 10^{-10}$ \\
5F-AMB & $100.00,100.00$ & $4.23 \times 10^{-10}$ & $100.00,98.91$ & $5.45 \times 10^{-10}$ \\
CP55940 & $100.00,100.00$ & $4.17 \times 10^{-10}$ & $100.00,100.00$ & $2.72 \times 10^{-10}$ \\
\hline
\end{tabular}

a Substance concentration $\left(1 \times 10^{-5}\right)$. Response rates are expressed as the mean values of duplicate samples.

分， 30 分及び 1 時間において，すべて陰性であつ た.「総統」曝露群では, 曝露後 15 分及び 30 分に 2 匹が陽性，1 時間に 1 匹が陽性となった。

\section{3. ガス回収瓶中の薬物成分分析 LC/PDA} と GC/EI-MS による分析の結果，1-2 はいずれ も, 燃焼による分解は確認できず，未変化体のまま 気化し, 薬物として作用することが明らかとなった (Figs. 5 and 6). また 2 本目のガス回収装置でも薬 物が検出されたことから，気化した成分は 1 本目の ガス回収装置ですべて捕集できるわけではないこと が判明した.

4. カンナビノイド受容体に対するアゴニスト活 性陽性物質（CP55940）及び被験物質 1-2 の トカンナビノイド受容体 $\left(\mathrm{CB}_{1}\right.$ 及び $\left.\mathrm{CB}_{2}\right)$ に対する 反応率及びアゴニスト活性（ $\mathrm{EC}_{50}$ 值）を Table 8 に示した。陽性物質の $\mathrm{CB}_{1}, \mathrm{CB}_{2}$ に対する $\mathrm{EC}_{50}$ 值 は，それぞれ $4.17 \times 10^{-10}, 2.72 \times 10^{-10}$ であった。 1-2 の $\mathrm{CB}_{1}$ に対する $\mathrm{EC}_{50}$ 值は，それぞれ $2.26 \times$ $10^{-10}, 4.23 \times 10^{-10}, \mathrm{CB}_{2}$ に対する $\mathrm{EC}_{50}$ 值は，それ ぞれ $1.52 \times 10^{-10}, 5.45 \times 10^{-10}$ であり，1-2 とも陽 性物質と同等の強いアゴニスト活性を持つことが明 らかになった。

\section{考察}

大麻を吸煙した場合，吸煙から数分以内に作用が 発現する6)ことから，危険ドラッグ吸入曝露試験に おける行動観察及び中枢・自律神経症状観察等は, 燃焼終了後 15 分, 30 分, 1 時間に実施した。マー シュマロウリーフのみを燃焼させた陰性対照群にお いても，洗顔運動の抑制や眼瞼の下垂，体温の低下 等が認められたが，それらの作用強度は燃焼終了後 15 分が最も強く, 時間の経過に伴って減弱し， 1 時 間の観察時にはほとんど認められなくなつた。それ に対し,「総統」曝露群では, 燃焼終了後 15 分から
極めて多くの観察項目において，強い作用強度での 影響が現れ，1 時間の観察時においても強い作用強 度を維持していた．陰性対照群と「総統」曝露群の 両方で影響のみられた観察項目の作用強度を比較す ると, 燃焼終了後 15 分の眼瞼下垂を除き，「総統」 曝露群の方がより作用強度が強かった.

大麻の主要なカンナビノイド成分であるテトラヒ ドロカンナビノール (tetrahydrocannabinol; THC) を実験動物に投与すると，体温低下, ${ }^{6-8)}$ 自発運動 量の低下, ${ }^{7)}$ 鎮痛7)（すなわち痛反応の抑制），除脈7) (すなわち心拍数の低下)，攻撃行動）（すなわち攻 撃性の克進), カタレプシー6-8)を引き起こすことが 知られている。「総統」曝露群において，体温低下 (曝露 1 時間後に平均 $5.9^{\circ} \mathrm{C}$ ), 自発運動量の低下 (Table 5-1)，痛反応の抑制（Table 4)，心拍数の低 下 (Table 6), 攻撃性の亢進 (Table 4), カタレプ シー（Table 7）がみられたことから，本吸入曝露 試験によりカンナビノイドに特徵的な薬理作用を確 認できると考えられた.

ヒトカンナビノイド受容体 $\left(\mathrm{CB}_{1}\right.$ 及び $\left.\mathrm{CB}_{2}\right)$ に対 するアゴニスト活性（EC 50 值）は， 1-2 とも陽性 物質と同等レベルの強さを示し,「総統」曝露群の 行動及び中枢・自律神経症状観察，カタレプシー試 験でみられた強い作用を裏付けた。

煙中の薬物を捕える方法としてガス回収装置を用 いたが，その溶媒として，合成カンナビノイドは有 機溶媒に溶け易い性質を有するため，1 本目のガス 回収装置にはアセトニトリルを使用し，2 本目のガ 又回收装置には燃焼に伴う分解物など広範囲な薬物 を溶解させることを目的としてジメチルスルホキシ ドを回収液として使用した．燃焼に伴う薬物の変化 は，支持植物の燃焼に由来する成分（ネガティブコ ントロール（マーシュマロウリーフのみ）との比較 により検証することができると考えられた．現在ま 
でに多数の合成カンナビノイドが，東京都内で流通 していた実態がわれわれの調査で確認されてお り, ${ }^{9-16)}$ それらの一部についてはカンナビノイド受 容体に対するアゴニスト活性は高いと報告してき た. ${ }^{15,16)}$ また合成カンナビノイドの流行は日本だけ でなく，欧州や米国等においても報告されてお り, ${ }^{17,18)}$ 深刻な社会現象となっている.

今回は「総統」に含まれる 1 及び $\mathbf{2}$ の薬物につい て検証したが, 今後, 化学構造が異なる合成カンナ ビノイドにおいても，本法を用いれば燃焼に伴う薬 物の変化を検証できると考えられる.

これらの結果から，マーシュマロウリーフを陰性 対照として用い, 曝露後 15 分, 30 分, 60 分に行動 及び中枢・自律神経症状観察，カタレプシー試験を 実施し，かつ煙中の薬物を解析できる本吸入曝露試 験は，合成カンナビノイドを成分とするハーブ系危 険ドラッグの生体影響を評価するスクリーニング法 として，摂取方法に即した有用な試験法と考えられ る.

利益相反＼cjkstart開示すべき利益相反はない.

\section{REFERENCES}

1) Fukumori N., Ando H., Kubo Y., Yuzawa K., Nagasawa A., Takahashi H., Yano N., Fuwa T., Ogata A., Uehara S., Ann. Rep. Tokyo Metr. Inst. Pub. Health, 58, 293-297 (2007).

2) Fukumori N., Ando H., Kubo Y., Yuzawa K., Nagasawa A., Takahashi H., Yano N., Huwa T., Oohashi N., Ogata A., Ann. Rep. Tokyo Metr. Inst. Pub. Health, 59, 329-334 (2008).

3) Satoh K., Fukumori N., Fuwa T., Tanaka T., Ann. Rep. Tokyo Metr. Inst. Pub. Health, 60, 21-35 (2009) .

4) Ogata A., Satoh K., Fuwa T., Tanaka T., Nagasawa A., Yuzawa K., Yano N., Ando H., Kubo Y., Takahashi H., Ohyama K., Miyazawa M., Kojima T., Yakugaku Zasshi, 133, 2529 (2013).

5) Irwin S., Psychopharmacologia(Berl.), 13, 222-257 (1968).

6) Inoue T., "Ranyou yakubutsu no kagaku,"
Tokyo Kagakudojin Co., Ltd., Tokyo, 2003, pp. 83-84.

7) Waku K., Yakugaku Zasshi, 126, 67-81 (2006).

8) Yamamoto I., Bulletin of Hokuriku University, 24, 1-23 (2000).

9) Nakajima J., Takahashi M., Seto T., Suzuki J., Forensic. Toxicol., 29, 51-55 (2011).

10) Nakajima J., Takahashi M., Seto T., Kanai C., Suzuki J., Yoshida M., Hamano T., Forensic. Toxicol., 29, 95-110 (2011).

11) Nakajima J., Takahashi M., Nonaka R., Seto T., Suzuki J., Yoshida M., Kanai C., Hamano T., Forensic. Toxicol., 29, 132-141 (2011).

12) Nakajima J., Takahashi M., Seto T., Yoshida M., Kanai C., Suzuki J., Hamano T., Forensic. Toxicol., 30, 33-44 (2012).

13) Nakajima J., Takahashi M., Seto T., Kanai C., Suzuki J., Yoshida M., Uemura N., Hamano T., Forensic. Toxicol., 31, 76-85 (2013).

14) Uemura N., Fukaya H., Kanai C., Yoshida M., Nakajima J., Takahashi M., Suzuki J, Moriyasu T., Nakae D., Forensic. Toxicol., 32, 45-50 (2014).

15) Nakajima J., Takahashi M., Uemura N., Seto T., Fukaya H., Suzuki J., Yoshida M., Kusano M., Nakayama H., Zaitsu K., Ishii A., Moriyasu T., Nakae D., Forensic. Toxicol., 33, 84-92 (2015).

16) Ichikawa Y., Nakajima J., Takahashi M., Uemura N., Yoshida M., Suzuki A., Suzuki J., Nakae D., Moriyasu T., Hosaka M., Forensic. Toxicol., 35, 146-152 (2017).

17) European Monitoring Ceutre for Drugs and Drug Addiction, "European Drug Report 2016: Trends and Developments," May 2016: 〈http://www.emcdda.europa.eu/system/files/ publications / 2637 / TDAT16001ENN.pdf $\rangle$, cited 17 March, 2017.

18) United Nations Office on Drugs and Crime “World Drug Report 2016.”: 〈http://www. unodc.org/doc/wdr2016/WORLD_DRUG_ REPORT_2016_web.pdf $\rangle$, cited 17 March, 2017. 